\title{
Utilization of the fish ladder at the Engenheiro Sergio Motta Dam, Brazil, by long distance migrating potamodromous species
}

\author{
Sérgio Makrakis***, Maristela Cavicchioli Makrakis**, Ricardo Luiz Wagner***, \\ João Henrique Pinheiro Dias**** and Luiz Carlos Gomes*****
}

Utilization of the fish ladder installed at the Engenheiro Sergio Motta Dam (also known as Porto Primavera) on the Paraná River, Southern Brazil, by long-distance migrating potamodromous species (sampling Protocol I), and ascending and descending movements (Protocol II) were evaluated. Three pools along the fish ladder (designated as lower, middle, and upper) were sampled monthly between December, 2004 and March, 2005 to determine the abundance of species in the ladder. The ascending and descending movements of the species in the ladder were also analyzed in the same period. In the samples for both protocols, 37 species representing 17 families and 5 orders (Characiformes, Siluriformes, Perciformes, Gymnotiformes, and Myliobatiformes) were recorded. Characiformes were represented by 21 species. Long- distance migratory species ( 11 species) predominated in the ladder ( $60 \%$ of the total number of individuals), with high abundance of Rhinelepis aspera (5645 individuals). For protocol I, mean abundance varied greatly among the months and pools, with lowest values in December and March for all pools, and highest in January for the lower pool due to high capture of $R$. aspera. Fish abundance declined from the lower to the upper pool, especially for $R$. aspera and Rhaphiodon vulpinus. For Protocol II, 17 species were recorded ascending the ladder, where Astyanax altiparanae and Leporinus friderici were the most abundant species (684 and 111 individuals, respectively). However, 18 species showed descending movements, with high captures of Metynnis maculatus and A. altiparanae (339 and 319 individuals, respectively). Twelve species (52\%) moved in both directions, and among the seven migratory species sampled, four were recorded ascending and descending, and three species only ascending the ladder. The fish ladder appears to selectively favor species with high swimming capabilities. Adiscussion is presented on the requirements for future research on attraction to the fish ladder entrance, downstream movements, fish utilization of the ladder, and impacts on spawning and rearing habitat both upstream and downstream of the dam.

A utilização da escada para peixes instalada na barragem Engenheiro Sergio Motta (também conhecida como Porto Primavera) no rio Paraná, no sudeste do Brasil, por espécies potamódromas de longa distância (protocolo I) e os movimentos ascendentes e descendentes (protocolo II) foram avaliados. Três tanques ao longo da escada para peixes (denominados como foz, meio e tomada) foram amostrados mensalmente entre dezembro de 2004 a março de 2005 para avaliar a abundância de espécies na escada. Os movimentos ascendentes e descendentes das espécies na escada foram analisados no mesmo período. Nas amostragens relativas aos protocolo I e II, foram capturadas 37 espécies representando 17 famílias e cinco ordens (Characiformes, Siluriformes, Perciformes, Gymnotiformes e Myliobatiformes). Os Characiformes foram representados por 21 espécies. Espécies migradoras de longa distância (11 espécies) predominaram (60\% do total), com maior abundância de Rhinelepis aspera (5645 indivíduos). A abundância média variou entre os meses e tanques para o protocolo I, com menores valores em dezembro e março para todos os tanques, e maiores em janeiro no tanque foz, devido a maior captura de $R$. aspera. A abundância de peixes diminuiu do tanque foz para o tanque tomada, especialmente para R. aspera e Rhaphiodon vulpinus. Nas capturas relativas ao protocolo II, foram capturadas 17 espécies ascendendo a escada: Astyanax altiparanae e Leporinus friderici foram as mais abundantes (com 684 e 111 indivíduos, respectivamente). Entretanto, 18 espécies apresentaram movimentos descendentes, com elevadas capturas de Metynnis maculatus e A. altiparanae (339 e 319 indivíduos, respectivamente). Doze espécies apresentaram movimentos ascendentes e descendentes na escada, e das sete espécies migradoras amostradas, quatro apresentaram movimentos para cima e para baixo, e três espécies somente subiram. Esta escada para peixes parece favorecer seletivamente espécies com elevada capacidade de natação. As necessidades de pesquisas futuras para elucidar sobre a atratividade da escada, movimentos descendentes, utilização da escada pelos peixes e os impactos sobre as áreas de reprodução e criadouros, ambos a montante e jusante da barragem, são discutidos.

Key words: Paraná River, Migratory fish, Transposition, Fish passage.

\footnotetext{
*Universidade Estadual de Maringá, Av. Colombo, 5790.87020-9000 Maringá, PR, Brazil. makrakis@terra.com.br

**Universidade Estadual do Oeste do Paraná, Rua da Faculdade, 645.85903-330 Toledo, PR, Brazil. mcaviccm@hotmail.com

***FUNIVERSITÁRIA. Rua da Faculdade, 645. 85903-330 Toledo, PR, Brazil. ricardo_wagner@ibest.com.br

****Companhia Energética de São Paulo (CESP). Rodovia Marechal Rondon, km 667. 16920-000 Castilho, SP, Brazil. joao.dias@cesp.com.br;

*****Núcleo de Pesquisas em Limnologia, Ictiologia e Aquicultura and Departamento de Biologia, Universidade Estadual de Maringá.

87020-9000 Av. Colombo, 5790. Maringá, PR, Brazil.1cgomes@nupelia.uem.br
} 


\section{Introduction}

The seasonal movements exhibited by potamodromous fish usually involve upstream migration of spawning adults when floods occur (Lucas \& Baras, 2001; Harvey \& Carolsfeld, 2003). In the Paraná River (located within Brazil), migratory fish species usually spawn in the upper parts of large tributaries, and nursery areas are lagoons in the lower reaches and along the Paraná River banks (where a floodplain is located) and islands (Agostinho et al., 2003). Therefore, the persistence of most migratory fish species in the Paraná River basin depends on the availability of floodplain prompted by the lateral connectivity resulting from the flood pulse (Agostinho et al., 2003).

Nevertheless, large dams and their reservoirs, such as Yacyretá, Itaipu and Engenheiro Sergio Motta, drastically modified the landscape and altered the physical and chemical features of the Paraná River waters. Dams also decreased longitudinal and lateral connectivity of the river and its associated floodplain, disrupting migrations (Agostinho et al., 2004). Thus, the construction of fish passage facilities may minimize the impacts of dams on movements of migratory fish (Godoy, 1985; Prosser, 1986). In the main channel of the Paraná River, fish elevators were installed at the Yacyretá Dam in 1990. Another elevator and a fish ladder were built at Engenheiro Sergio Motta Dam in 1999 and 2001, respectively. In addition, a $10 \mathrm{~km}$ long lateral channel, the Canal da Piracema, was constructed near the Itaipu Dam (operation started in December, 2002). This canal includes several ladders and it is considered the longest of its type in the world (Carolsfeld, 2004).

However, fish passage facilities are recommended when there are appropriate areas upstream for spawning and development (nurseries) of migratory fish. In addition, translocation of fish must not affect the abundance of stocks downstream of dams, and consequently, fish movements in fish passages should be monitored. Nevertheless, monitoring tends to focus on economically important species (less than $5 \%$ of those found in reservoirs) because their commercial value is easily quantified (Agostinho et al., 2002). Moreover, no study mentions the true value of the biodiversity (Lucas $\&$ Baras, 2001), because most of the species that use fish passage facilities have low direct economic value.

This study evaluated the fish ladder constructed at the Engenheiro Sergio Motta Dam. Specifically, we identified which fish species used the ladder and compared these results to data recorded below the dam. Also, we analyzed the number of individuals (abundance) in three pools along the ladder to evaluate possible selectivity. In addition, we experimentally controlled the operation of the ladder to investigate which species showed ascending and descending movements in the ladder, because there are few studies in the Neotropical region considering this issue. Emphasis was given to longdistance migratory fish species.

\section{Material and Methods}

\section{Study area}

The Paraná River is formed by the junction of the Grande and Paranaíba rivers in South-Central Brazil, and flows into the La Plata River in northern Argentina. It is the tenth longest river in the world and the second in South America $(4,695$ $\mathrm{km})$. It has a $2.6 \times 10^{6} \mathrm{~km}^{2}$ drainage area that includes most of the south-central part of South America. Dams are one of the most common signs of human interference in this basin, in addition to agricultural land use.

The Engenheiro Sergio Motta hydroelectric powerplant belongs to the Companhia Energética de São Paulo (CESP). It can generate $1800 \mathrm{MW}$ of hydroelectricity and has a 220,000ha reservoir. The dam is $13 \mathrm{~km}$ wide, $22 \mathrm{~m}$ high, and it is located in the main channel of the Paraná River, along the border between São Paulo and Mato Grosso do Sul, Brazil (Fig. 1). A fish ladder (tweir and orifice type) was built on the left side of the dam, allowing fish to reach the reservoir. The ladder ends immediately below the powerhouse.

The ladder is $520 \mathrm{~m}$ long and its upper end is next to the reservoir at an elevation of $255.5 \mathrm{~m}$ (entrance of water), while the lower end is at an elevation of $235.5 \mathrm{~m}$, entering into the Paraná River at an angle of $45^{\circ}$. Fifty concrete weirs form the pools, and each pool is $5 \mathrm{~m}$ wide $\mathrm{x} 2 \mathrm{~m}$ high. These weirs are 8 $m$ apart from each other, and each one has six orifices (three at the upper side and three at lower side). In addition, each weir has four moving metal plates (two upper and two lower), which allow the closing of the orifices, altering the configuration of the water flow and creating distinct conditions for fish move-

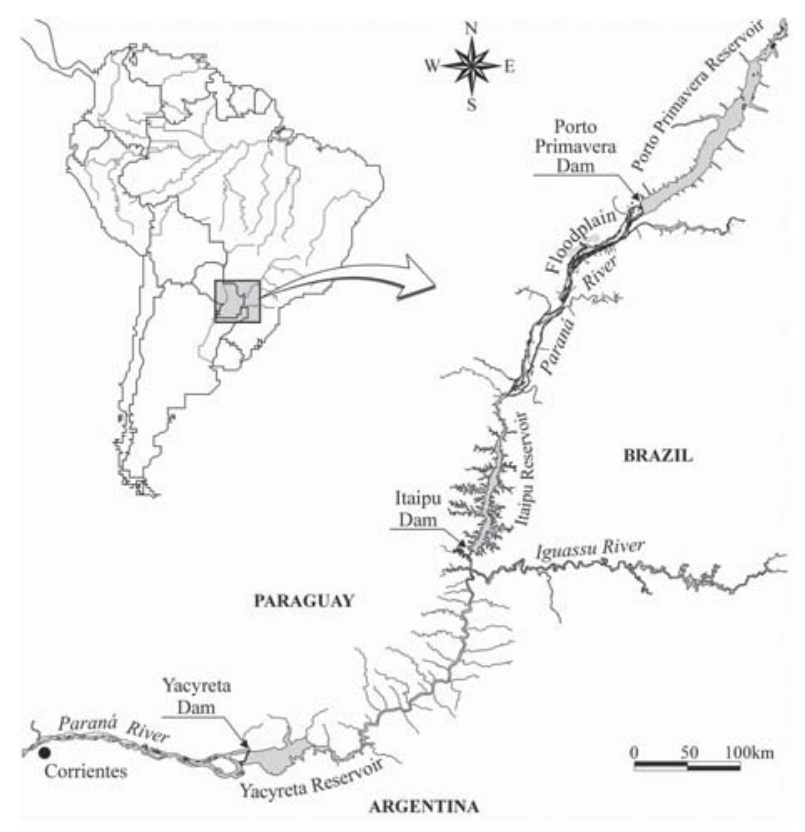

Fig. 1. Location of the Engenheiro Sergio Motta (Porto Primavera) Hydroelectric power plant in the Paraná River, Brazil. 


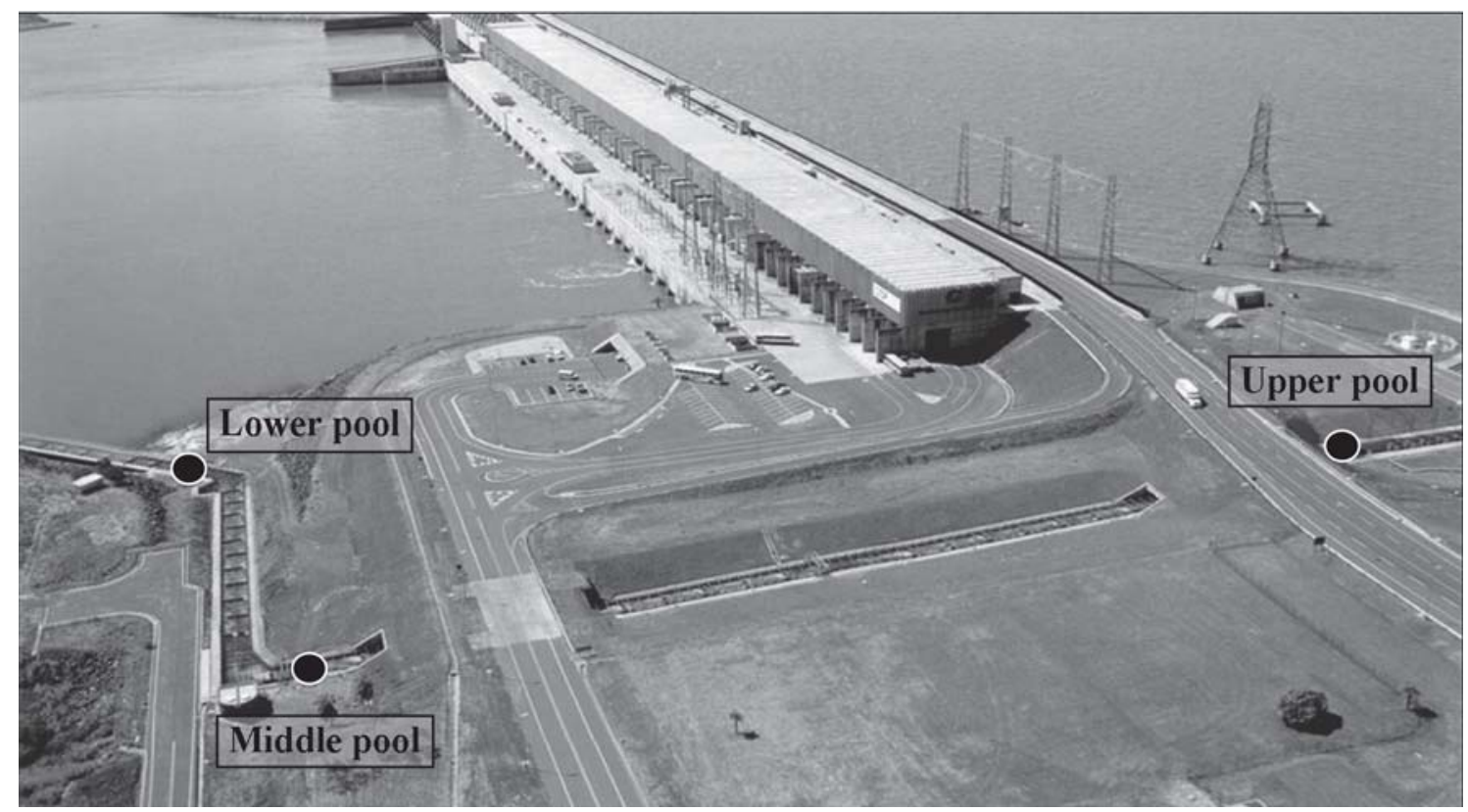

Fig. 2. Fish ladder and the powerhouse of Engenheiro Sergio Motta Dam.

\section{Data collection}

Samples were taken monthly between December, 2004 and March, 2005, at 8-h intervals (8h, 16h and 24h), during a period of two days. Three pools of the ladder were sampled: one located near the Paraná River (lower pool), another at the middle of the ladder (middle pool) and the third near the reservoir (upper pool) (Fig. 2). Two study protocols were used. In Protocol I, the upper orifices of each pool (lower, middle and upper) were always closed with small-meshed metal plates to avoid the entrance of descending fish. We then progressively reduced the water flow in the ladder, and simultaneously, the lower orifices of the selected pools were closed, keeping fish inside the pools. Fish were captured by seine nets and dip nets, and stored inside tanks supplied with oxygen. After removal of all fish, they were identified (according to Ringuelet et al., 1967 and Britski, 1972), counted and released to the ladder in the pool immediately above.

After collecting for Protocol I, we proceeded to sample according to Protocol II. We collected monthly samples (between December, 2004 and March. 2005) to evaluate ascending and descending fish movements. We closed the entrance of the ladder in the upper pool and progressively reduced the water flow, to remove all fish inside the ladder $24 \mathrm{~h}$ before sampling. At the middle weir, we inserted meshed metal plates in the orifices, to prevent fish from entering or leaving the pool. Water flow in the ladder was then reestablished and after $18 \mathrm{~h}$, it was closed again. Simultaneously, we inserted additional meshed metal plates to close orifices of the lowest and the uppermost pools. All fish were identified, counted and released to the ladder.

\section{Data analysis}

Fish species using the ladder. To characterize the ichthyo- fauna using the ladder, we considered the samples obtained in both protocols (I and II). Taxonomic positions of the species were used to identify the orders and families with greater number of species. Species that contributed more than $95 \%$ of the total number of individuals had their abundance represented graphically. Species were also grouped according to their life strategies, as follows: i) long distance migratory species (LDMI); ii) sedentary species that do not develop parental care (SNPC); iii) sedentary species that develop parental care (SPC); iv) sedentary species with internal fertilization and external development (SIFE); and v) sedentary species with internal fertilization and internal development (SIFI) (Vazzoler, 1996; Agostinho et al., 2003; Suzuki et al., 2004). These analyses primarily aimed to represent the importance of migratory species in relation to the total captured in the ladder.

Selectivity of the ladder (Protocol I) . We described the temporal occurrence of all species because fish movements are seasonal. Abundance (number of individuals) of all species and of migratory alone was determined considering months and pools sampled. We also obtained the percentage of individuals for migratory species that ascended the ladder. Thus, the total number of sampled individuals $\left(\mathrm{Q}_{\mathrm{a}}\right)$ of a species in a given pool (lower, middle and upper) was divided by the total number of individuals of the species $\left(Q_{t}\right)$, captured in all pools or $\left(Q_{a} / Q_{t}\right) \times 100$.

Ascending and descending movements (Protocol II). In this topic, we also examined the temporal occurrence of the species, from December 2004 to March 2005. The number of individuals of all species was summed, and the totals ascending and descending the ladder were represented graphically (emphasis was given to long-distance migratory species). 


\section{Results}

\section{Fish species using the ladder}

During the period between December, 2004 and March, 2005, 10,273 individuals were captured in both protocols. These individuals belonged to 37 species, 17 families and 5 orders, according to Reis et al. (2003).

Characiformes predominated with 21 species, and families with high a number of species were Characidae, Anostomidae and Pimelodidae (8, 7 and 6 species, respectively). Long-distance migratory species (LDMI) predominated (60.08\%; most abundant species was Rhinelepis aspera with 5,645 individuals), followed by sedentary lacking parental care (SNPC; 27.01\%). Among the main species, Pimelodus maculatus, Leporinus obtusidens, L. elongatus, Pimelodus ornatus and Rhaphiodon vulpinus, are all long-distance migrants, but overall they showed low abundances in the ladder (Fig. 3).

\section{Selectivity of the ladder (Protocol I)}

We collected 8,416 individuals in this protocol that belonged to 31 species (9 long-distance migrants). The greatest number of species was recorded in February (22) followed by January (19). However, December and March had the lowest number of species (15 each). The number of migratory spe-

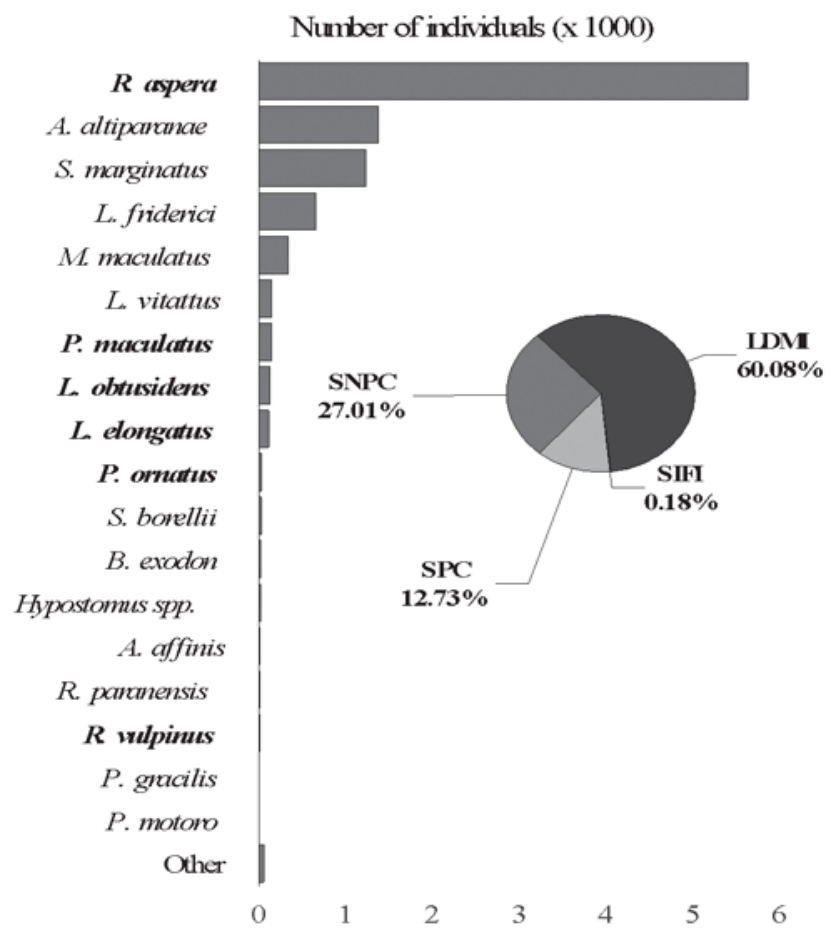

Fig. 3. Number of individuals of the main species and proportions of the life strategies (LDMI: long distance migratory species; SNPC: sedentary species that do not develop parental care; SPC: sedentary species that develop parental care; SIFI: sedentary species with internal fertilization and internal development) sampled in both protocols conducted in the fish ladder located at Engenheiro Sergio Motta Dam (Migratory species are in bold). cies showed a similar trend, with 8, 6, 5 and 5 species, respectively (Table 1).

Mean abundance (per month and pool) varied widely during the sampling period. Low values were recorded in December and March (all pools), whereas the greatest abundance occurred in January (mainly in the lower pool), and February had intermediate but low values. The greatest value in January was due to the high abundance of $R$. aspera. The second greatest value was a result of the high abundance of Serrasalmus marginatus in the morning and at night (Fig. 4a). As the abundance of migratory fish was highly influenced by the capture of $R$. aspera, the trend for migratory species was the same as that described above, except in January, when there was a clear reduction in the number of individuals in the direction to the upper pool (Fig. 4b).

The percentages of individuals that ascended the ladder were distinct for the migratory species, but with a sharp reduction from the lower to the upper pool, especially for $R$. aspera (most abundant) and $R$. vulpinus. However, for $L$. elongatus, L. obtusidens, and P. maculatus, the features of the fish ladder did not appear to limit their movements (Fig. 5).

\section{Ascending and descending movements (Protocol II)}

We captured 1,797 individuals of 23 species (Table 2) in this protocol. We recorded 17 species ascending the ladder, and the most abundant species were $A$. altiparanae and $L$. friderici (684 and 111 individuals, respectively) (Fig. 6). How-
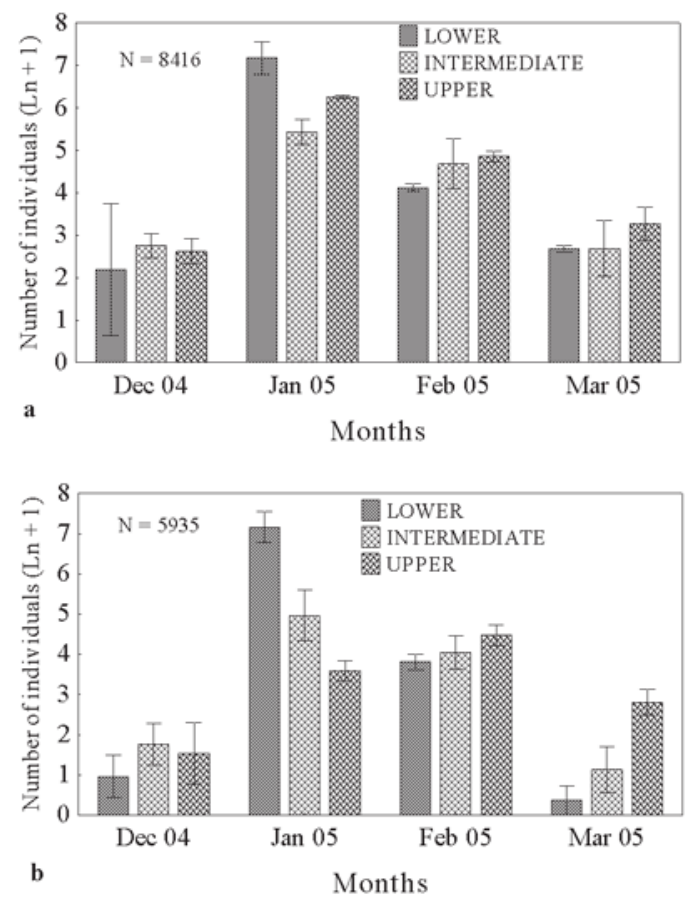

Fig. 4. Monthly averages of the total number of individuals ( \pm standard error) (a) and of migratory species (b), captured at intervals of $8 \mathrm{~h}$ in the different pools sampled in the fish ladder located at Engenheiro Sergio Motta Dam (N: total number of individuals). 
Table 1. Species sampled in Protocol I conducted at the fish ladder of Engenheiro Sergio Motta Dam, during the period of December, 2004 to March, 2005. Migratory species are in bold.

\begin{tabular}{|c|c|c|c|c|}
\hline \multirow{2}{*}{\multicolumn{5}{|c|}{$\frac{\text { Species }}{\text { MYLIOBATIFORMES }}$}} \\
\hline & & & & \\
\hline \multicolumn{5}{|l|}{ Potamotrygonidae } \\
\hline Potamotrygon motoro & & + & & + \\
\hline \multicolumn{5}{|l|}{ CHARACIFORMES } \\
\hline \multicolumn{5}{|l|}{ Anostomidae } \\
\hline Leporellus vittatus & + & + & + & \\
\hline Leporinus elongatus & + & + & + & + \\
\hline Leporinus friderici & + & + & + & + \\
\hline Leporinus obtusidens & + & + & + & + \\
\hline Schizodon borellii & + & + & + & \\
\hline Schizodon nasutus & & + & + & \\
\hline \multicolumn{5}{|l|}{ Characidae } \\
\hline Astyanax altiparanae & + & + & + & + \\
\hline Bryconamericus exodon & + & + & & \\
\hline Metynnis maculatus & & & + & \\
\hline Myleus levis & & & + & \\
\hline Roeboides paranensis & & & + & + \\
\hline Salminus brasiliensis & & + & & \\
\hline Serrasalmus marginatus & + & + & + & \\
\hline \multicolumn{5}{|l|}{ Crenuchidae } \\
\hline Characidium aff. zebra & + & & & \\
\hline \multicolumn{5}{|l|}{$\begin{array}{l}\text { Curimatidae } \\
\text { lats }\end{array}$} \\
\hline Cyphocharax nagelii & & & + & \\
\hline \multicolumn{5}{|l|}{ Cynodontidae } \\
\hline Rhaphiodon vulpinus & & + & + & \\
\hline \multicolumn{5}{|l|}{ Parodontidae } \\
\hline Apareiodon affinis & & + & + & + \\
\hline \multicolumn{5}{|l|}{ Prochilodontidae } \\
\hline Prochilodus lineatus & & & + & \\
\hline \multicolumn{5}{|l|}{ SILURIFORMES } \\
\hline \multicolumn{5}{|l|}{ Auchenipteridae } \\
\hline Auchenipterus osteomystax & + & & & \\
\hline \multicolumn{5}{|l|}{ Heptapteridae } \\
\hline Pimelodella gracilis & + & & + & + \\
\hline \multicolumn{5}{|l|}{ Loricariidae } \\
\hline Hypostomus spp. & + & + & + & + \\
\hline Lyposarcus anisitsi & & + & & \\
\hline Rhinelepis aspera & & + & + & + \\
\hline \multicolumn{5}{|l|}{ Pimelodidae } \\
\hline Iheringichthys labrosus & & & & + \\
\hline Pimelodus maculatus & + & + & + & + \\
\hline Pimelodus ornatus & + & + & + & + \\
\hline Pseudoplatystoma corruscans & + & & + & \\
\hline Sorubim lima & & & + & + \\
\hline \multicolumn{5}{|l|}{ GYMNOTIFORMES } \\
\hline \multicolumn{5}{|l|}{ Sternopygidae } \\
\hline Eigenmannia spp. & & & & + \\
\hline \multicolumn{5}{|l|}{ PERCIFORMES } \\
\hline \multicolumn{5}{|l|}{ Cichlidae } \\
\hline Cichla spp. & & + & & \\
\hline TOTAL & 15 & 19 & 22 & 15 \\
\hline
\end{tabular}

ever, we recorded 18 species descending the ladder, and the most abundant species were $M$. maculatus and A. altiparanae (339 and 319 individuals, respectively). Twelve species (52\%) exhibited ascending and descending movements. No descending movements were observed in March, 2005.

Seven species were long-distance migratory and four of them demonstrated both ascending and descending movements: L. elongatus, L. obtusidens, P. maculatus, and $R$. vulpinus (Table 2). The most abundant migratory species ascending the fish ladder were L. obtusidens and $R$. aspera (70 and 31 individuals, respectively) (Fig. 6). Moreover, four migratory species were captured performing descending movements, and they were: L. elongatus (7 individuals) and L. obtusidens (16 individuals), both in all months; P. maculatus (3 individuals) in January and February of 2005; and, finally, $R$. vulpinus (4 individuals) in February, 2005. Three migratory species (Pterodoras granulosus, Prochilodus lineatus and $R$. aspera) did not display descending movements.

\section{Discussion}

The number of species recorded (37) at the fish ladder of Engenheiro Sergio Motta Dam was lower than that found for the Paraná River, in the stretch immediately below (331 species) (Agostinho \& Julio Jr., 1999; Agostinho et al., 2005). Similarly, the number of migratory species in the ladder (11 species) was also lower than the number recorded in the same stretch (18 species) (Agostinho et al., 2003; Suzuki et al., 2004). The lower number of migratory species using the ladder may be due to the sampling effort employed in this study (three pools; four months) which could not include the seasonal movements of all migratory species present in the region. In addition, these results may indicate possible problems either in the attraction of the ladder or in selecting the species that can move through it. These problems may also be present in other ladders (Agostinho et al., 2007b) and lateral channels (Makrakis et al., 2007). In spite of several studies stating that ladders are successful fish passage structures (Quirós, 1988), species selectivity seems not to have been seriously evaluated yet. Selectivity is inherent to any fish passage and should always be subject to detailed analysis (Larinier, 2002; Agostinho et al., 2002, 2007a).

Selectivity of the ladder at Engenheiro Sergio Motta was observed when the abundance data in the three pools were analyzed. The reductions in the number of individuals from the lower to the upper pool, suggest that the ladder is selective, even for some migratory species (R. aspera and $R$. vulpinus). This may lead to delays in the migration of these species, a consequence that should be avoided (Larinier, 2002). However, other species, such as L. elongatus, L. obtusidens, and P. maculatus, appeared to move in the ladder without major difficulties. These species are among the best swimmers in the basin and their morphology (fusiform bodies), strategy of swimming near the bottom (P. maculatus), and the ability to jump (L. elongatus and L. obtusidens) all provide benefits to the species successful movement in the ladder. This was also observed in parts of the Canal da Piracema, located near the Itaipu Dam (Makrakis et al., 2007) and in other parts of the world (Larinier, 2002).

Data on discharge, water velocity and turbulence, fish size, behavior and swimming performance should be analyzed to determine the variables that influence movements in the ladder. This would provide information to improve the efficacy of this fish passage. However, caution is necessary because the ladder may be reducing the abundance of the already depleted stocks downstream of Engenheiro Sergio Motta Dam, as stated by Agostinho et al. (2002). Thus, the 


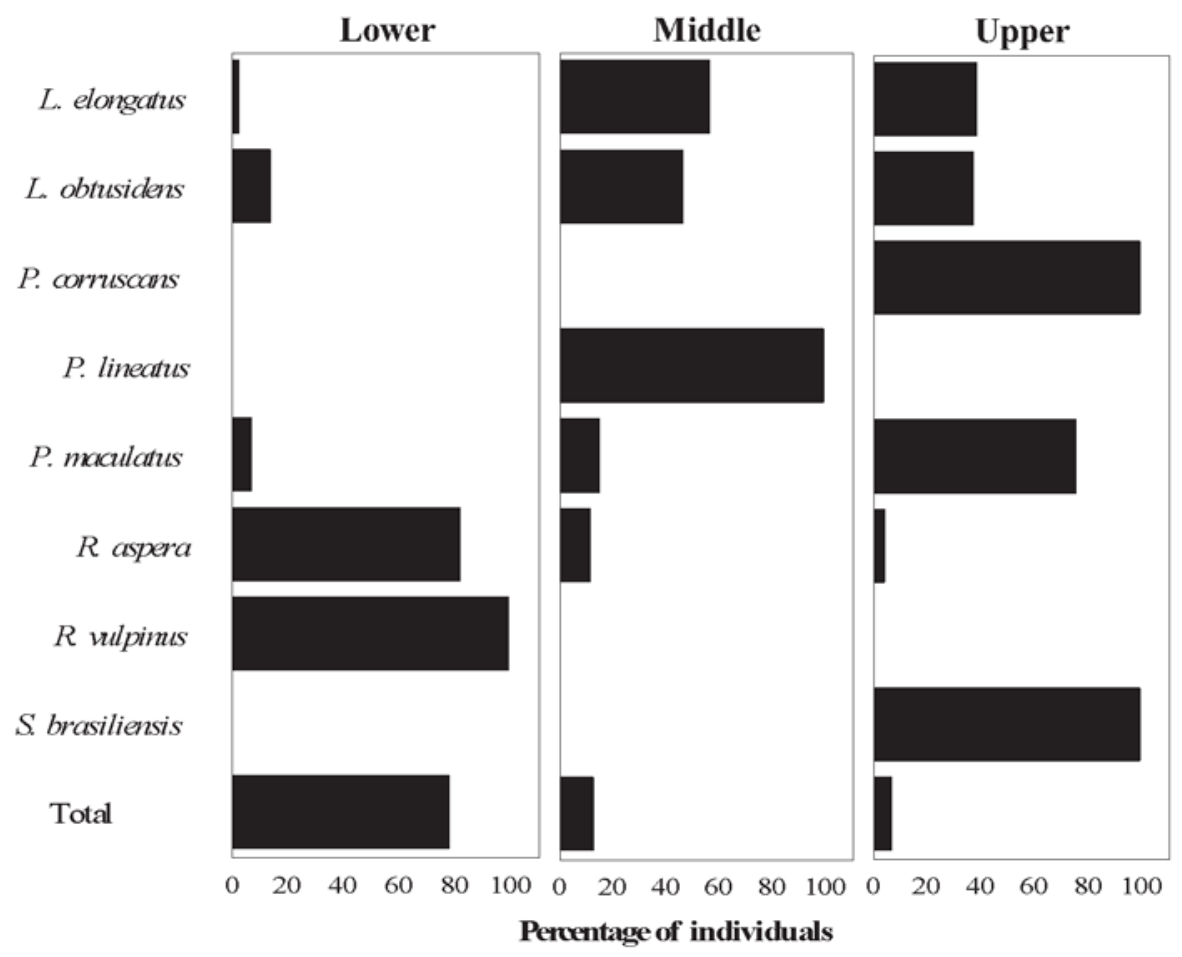

Fig. 5. Percentage of individuals of migratory species in the pools sampled in the ladder located at Engenheiro Sergio Motta Dam.

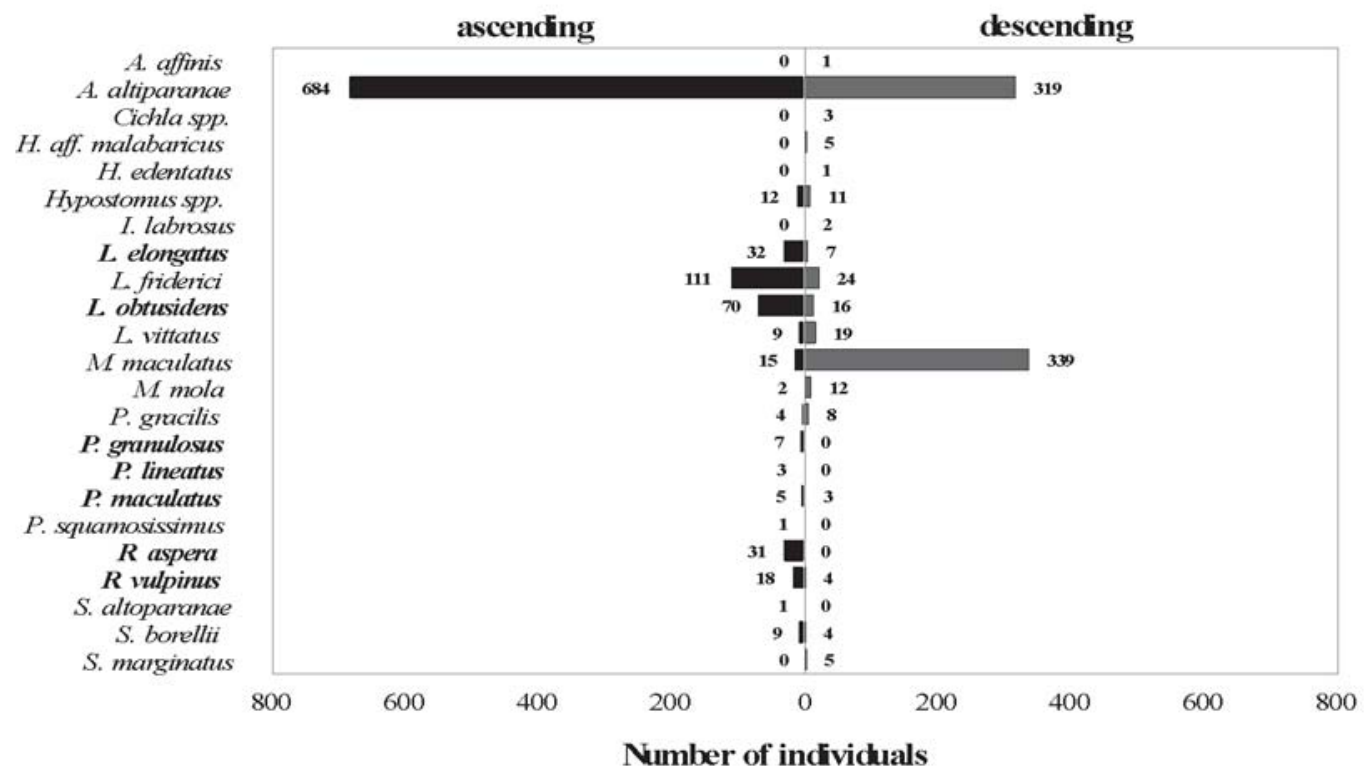

Fig. 6. Number of individuals for species captured in Protocol II (assessment of ascending and descending movements). Migratory species are in bold.

ladder would be undesirable if suitable places for spawning and development (nurseries) for migratory species are unavailable upstream.

Concern should be given to the intense ascent of $R$. aspera. This species showed a sharp decline in the fishery at the Itaipu Reservoir (downstream from Engenheiro Sergio Motta Dam). The main reasons for this include overfishing, habitat degradation (sanding and removal of rocks in its pref- erential habitat) and diseases (Okada et al., 2005). If this species is not able to spawn or develop above Sergio Motta Dam, its population size could be further reduced downstream.

Another fundamental aspect about the efficacy of a fish passage facility in contributing to the conservation of fish stocks is the possibility of downstream movements of adults (return) and juveniles (recruitment downstream) (Agostinho et al., 2002, 2007a). Protocol II showed that the movements of 
Table 2. Species occurrence in Protocol II, performed to evaluate ascending (Asc) and descending (Desc) movements in the fish ladder of Engenheiro Sergio Motta Dam, during the period of December, 2004 to March, 2005. Migratory species are in bold.

\begin{tabular}{|c|c|c|c|c|c|c|c|c|c|c|}
\hline \multirow{2}{*}{ Species } & \multicolumn{2}{|c|}{ December } & \multicolumn{2}{|c|}{ January } & \multicolumn{2}{|c|}{ February } & \multicolumn{2}{|c|}{ March } & \multicolumn{2}{|c|}{ TOTAL } \\
\hline & Asc & Desc & Asc & Desc & Asc & Desc & Asc & Desc & Asc & Desc \\
\hline CHARACIFORMES & & & & & & & & & & \\
\hline Anostomidae & & & & & & & & & & \\
\hline Leporellus vittatus & + & + & + & + & & + & + & & + & + \\
\hline Leporinus elongatus & + & + & + & + & + & + & + & & + & + \\
\hline Leporinus friderici & + & + & + & & + & + & + & & + & + \\
\hline $\begin{array}{l}\text { Leporinus obtusidens } \\
\text { Schizodon altoparanae }\end{array}$ & + & + & $\begin{array}{l}+ \\
+\end{array}$ & + & + & + & + & & $\begin{array}{l}+ \\
+\end{array}$ & + \\
\hline $\begin{array}{l}\text { Schizodon borellii } \\
\text { Characidae }\end{array}$ & + & + & + & & + & + & & & + & + \\
\hline Astyanax altiparanae & & + & + & + & + & + & + & & + & + \\
\hline Metynnis maculatus & + & + & + & + & & & & & + & + \\
\hline Metynnis mola & & & + & + & & + & & & + & + \\
\hline $\begin{array}{l}\text { Serrasalmus marginatus } \\
\text { Cynodontidae }\end{array}$ & & & & & & + & & & & + \\
\hline $\begin{array}{l}\text { Rhaphiodon vulpinus } \\
\text { Erythrinidae }\end{array}$ & & + & & & + & + & + & & + & + \\
\hline $\begin{array}{l}\text { Hoplias aff. malabaricus } \\
\text { Parodontidae }\end{array}$ & & + & & + & & & & & & + \\
\hline Apareiodon affinis & & & & + & & & & & & + \\
\hline Prochilodontidae & & & & & & & & & & \\
\hline $\begin{array}{l}\text { Prochilodus lineatus } \\
\text { SILURIFORMES }\end{array}$ & & & + & & + & & & & + & \\
\hline $\begin{array}{l}\text { Pterodoras granulosus } \\
\text { Heptapteridae }\end{array}$ & + & & & & & & & & + & \\
\hline $\begin{array}{l}\text { Pimelodella gracilis } \\
\text { Loricariidae }\end{array}$ & & + & & & + & + & & & + & + \\
\hline Hypostomus spp. & + & + & & + & + & + & + & & + & + \\
\hline $\begin{array}{l}\text { Rhinelepis aspera } \\
\text { Pimelodidae }\end{array}$ & + & & & & + & & & & + & \\
\hline Hypophthalmus edentatus & & & & + & & & & & & + \\
\hline Iheringichthys labrosus & & + & & & & & & & & + \\
\hline $\begin{array}{l}\text { Pimelodus maculatus } \\
\text { PERCIFORMES } \\
\text { Cichlidae }\end{array}$ & & & + & + & + & + & & & + & + \\
\hline $\begin{array}{l}\text { Cichla spp. } \\
\text { Sciaenidae }\end{array}$ & & & & + & & + & & & & + \\
\hline Plagioscion squamosissimus & + & & & & & & & & + & \\
\hline
\end{tabular}

at least some species (52\%) are bidirectional. Nevertheless, most individuals of migratory species were captured ascending the ladder. For descending movements, small-sized nonmigratory species were frequent. This protocol should be adjusted to allow a better evaluation of descending movements, because species may have been attracted to the ladder when the water flow was reestablished.

Data from Protocol II were important because it clearly indicated that descending movements did occur. This possibility, as mentioned, is fundamental since Engenheiro Sergio Motta Dam is located immediately above an area used as a nursery by migratory fish. In this region, they find adequate places for spawning (in large tributaries; Agostinho et al., 2003; Agostinho et al., 2005). Therefore, the movements in the ladder should be monitored, including the months when spawning does not occur. If descending movements of adults and/or juveniles of migratory species do not occur, the operation of the ladder must be carefully evaluated.

Another problem identified in the ladder is the presence of exotic (Plagioscion squamosissimus and Cichla spp.) and native (Serrasalmus marginatus and Rhaphiodon vulpinus) predators. The presence of these species may be linked to the presence of forage fish (Astyanax altiparanae and Bryconamericus exodon, among others). The impacts of predation on migratory species indicate the importance of quantifying delays at dams. Apparently, the design and operation of the ladder are advantageous for predator species, probably because it concentrates large number of prey in a small area. Ladders with weirs and orifices conceived to translocate fish in the temperate zone may not be adequate for Neotropical fish species, because such designs enhance predation, and consequently, this could ultimately inhibit the movements of migratory fish. Therefore, the design and operation of fish ladders in the Neotropical region must be reviewed in light of local biological and behavioral features of migratory species. Similar problems were already identified in the fish ladder of Lajeado dam (Agostinho et al., 2007b). Other types of fish passages should be considered, such as channels that simulate natural rivers (Jungwirth, 1996; Jungwirth et al., 1998, Parasiewicz et al., 1998).

The fish ladder of Engenheiro Sergio Motta Dam appeared to be selective for certain species, including some long-dis- 
tance migratory fish. The most successful species ascending the ladder were those with great swimming capability, and the swimming behavior may have implications for passage efficiency. Future investigations are required to better evaluate this problem, e.g., assessments of fish behavior (swimming behavior and rate of predation), attractions and guidance efficiency, passage efficiency through the ladder, time of passage and delay. Cameras and electronic tags (telemetry and/ or PIT) may be used for monitoring fish ladders. Additionally, studies should include those on the occurrence and abundance of eggs and fish larvae, as well as of juveniles, immediately below and above the dam, to determine the availability of suitable spawning and nursery areas. This information will be essential to determine the real role of the ladder and how it should be operated.

\section{Acknowledgments}

We thank Companhia Energética de São Paulo (CESP) for financial and logistic support to carry out this work.

\section{Literature Cited}

Agostinho, A. A., L. C. Gomes, D. R. Fernandez \& H. I. Suzuki. 2002. Efficiency of fish ladders for neotropical ichthyofauna. River Research and Application, 18(3): 299-306.

Agostinho, A. A., L. C. Gomes \& F. M. Pelicice. 2007a. Ecologia e Manejo de Recursos Pesqueiros em Reservatórios do Brasil. Maringá, Eduem, 501p.

Agostinho, A. A., L. C. Gomes, H. I. Suzuki \& H. F. Júlio Jr. 2003. Migratory fishes of the Upper Paraná River Basin Brazil. Pp. 19-89. In: Carolsfeld, J., B. Harvey, C. Ross \& A. Baer (Eds.). Migratory fishes of South America: Biology, Fisheries and Conservation Status. Vitoria: World Bank, 372p.

Agostinho, A. A., L. C. Gomes, L. C. Veríssimo \& E. K. Okada. 2004. Flood regime, dam regulation and fish in the Upper Paraná River: effects on assemblage attributes, reproduction and recruitment. Reviews in Fish biology and Fisheries, 14(1): 1119.

Agostinho, A. A. \& H. F. Júlio Jr. 1999. Peixes da bacia do alto rio Paraná. Pp. 374-400. In: Lowe-McConnell, R. H. (Ed.). Estudos ecológicos de peixes tropicais (translation), Edusp: São Paulo.

Agostinho, A. A., S. M. Thomaz \& L. C. Gomes. 2005. The conservation of the biodiversity waters. Conservation Biology, Blakwel, 19(3): 646-652.

Agostinho, C. S., A. A. Agostinho, F. M. Pelicice, D. A. de Almeida \& E. E. Marques. 2007b. Selectivity of fish ladders: a bottleneck in Neotropical fish movement. Neotropical Ichthyology, 5(2): 205-213.

Britski, H. A. 1972. Peixes de água doce do estado de São Paulo, sistemática. Pp. 79-108. In: Poluição e Piscicultura. São Paulo: USP. Instituto de Pesca.
Carolsfeld, J. 2004. Evolução da Questão de Passagens para Peixes: Similaridades entre o Canadá e o Brasil. In: Projeto peixes, pessoas e águas, Mecanismos de Transposição de Peixes Brasileiros. World Fisheries Trust.

Godoy, M. P. 1985. Aquicultura: atividade multidisciplinar, escadas e outras facilidades para passagens de peixes, estações de piscicultura. Florianópolis: ELETROSUL. 77p.

Harvey, B. \& J. Carolsfeld. 2003. Introduction: fishes of the floods. Pp. 5-18. In: Carolsfeld, J., B. Harvey, C. Ross \& A. Bare (Eds.). Migratory Fishes of South America: Biology, Fisheries and Conservation States. Vitoria: World Bank. 372p.

Jungwirth, M. 1996. Bypass channels at weirs as appropriate aids for fish migration in rhithral rivers. Regulated Rivers: Research and Management, 2: 483-492.

Jungwirth, M., S. Schmutz \& S. Weiss. 1998. Fish migration and fish bypasses. Fishing News Books, Oxford. 438p.

Larinier, M. 2002. Fishways: General considerations. Pp. 21-27. In: Larinier, M., F. Travade, J. P. Porcher (Eds.). Fishways: Biological basis, design criteria and monitoring. Bulletin Français de la Pêche et de la Pisciculture, 364 suppl.

Lucas, M. C. \& E. Baras. 2001. Migration of Freshwater Fishes. Blackwell Science Ltd. 420p.

Makrakis, S., L. C. Gomes, M. C. Makrakis, D. R. Fernandez \& C. S. Pavanelli. 2007. The Canal da Piracema at Itaipu Dam as a fish pass system. Neotropical Ichthyology, 5(2): 185-195.

Okada, E. K., A. A. Agostinho \& L. C. Gomes. 2006. Spatial and temporal gradients in artisanal fisheries of a large Neotropical reservoir, the Itaipu Reservoir, Brazil. Canadian Journal of Fisheries and Aquatic Sciences, 62(3): 714-724.

Parasiewicz, P. J. Eberstaller, S. Weiss \& S. Schmutz. 1998. Conceptual guidelines for nature-like bypass channels. Pp. 348362. In: Jungwirth, M., S. Schmutz \& S. Weiss (Eds.). Fish migration and fish bypasses. Oxford: Fishing News Books, Blackwell Science Ltd. 438p.

Prosser, N. S. 1986. An overview of reservoir fisheries problems and opportunities resulting from hydropower. Pp. 238-246. In: Hall, G. E. (Ed.). Reservoir fisheries management: strategies for 80's. Maryland: American Fisheries Society.

Quirós, R. 1988. Estructuras para assistir a los peces no salmónidos en sus migraciones: America Latina. Instituto Nacional de Investigación Y Desarollo Pesquero. FAO, 50p.

Reis, R. E., S. O. Kullender \& C. J. Ferraris Jr. 2003. Check list of the freshwater fishes of South and Central America. Edipucrs, Porto Alegre, 729p.

Ringuelet, R. A., R. A. Aramburú \& A. A. Aramburú. 1967. Los peces argentinus de água dulce. La Plata: Comission de Investigacion Científica. 602p.

Suzuki, H. I., A. E. A. M. Vazzoler (In Memorian), E. E. Marques, M. L. A. P Lizama \& P. Inada. 2004. Reproductive ecology of fish assemblages. Pp. 271-292. In: Thomaz, S. M., A. A. Agostinho \& N. S. Hahn (Eds). The Upper Paraná River Floodplain: physical aspects, ecology and conservation. Leiden: Backhuys Publishers. 393p.

Vazzoler, A. E. A. M. 1996. Biologia da Reprodução de Peixes Teleósteos: Teoria e Prática. EDUEM, Maringá, Paraná. 169p.

Received February 2007 Accepted May 2007 